\title{
A Review on Metabolic Syndrome and Nutrition
}

\author{
Banu Mesçi ${ }^{1, *}$, Ayşe Erbakan ${ }^{2}$ and Özge Telci Çaklili ${ }^{1}$ \\ ${ }^{1}$ Internal Medicine Department, İstanbul Medeniyet University, Turkey \\ ${ }^{2}$ Internal Medicine Department, Nisa Hospital, Turkey
}

\begin{abstract}
Metabolic syndrome can be defined as a disorder with occurrence of at least three out of five medical conditions including hyperglycemia, hypertriglyceridemia, high blood pressure, central obesity and low HDL cholesterol levels. In this review we will discuss how to improve poor eating habits which further escalates the risk of cardiovascular disease and diabetes. To treat and moreover to prevent metabolic syndrome, we should make healthy life style changes as our priority goal. Macro and micronutrient composition and metabolically favorable food components have a profound influence on health outcomes. Though Mediterranean and DASH diets are referred as the healthiest diets, there are numerous diets that are as well successful. Positive effects of low carbohydrate diets on glycemic regulation have been shown. Nonetheless, personalized nutrition applications with persistent implementation of these changes are foundations for success. A successful approach also needs regular exercise and behavioral changes.
\end{abstract}

Keywords: Metabolic syndrome, nutrition, diet, low carbohydrate diet, low fat diet, Mediterranean diet, DASH diet.

\section{INTRODUCTION}

Metabolic syndrome (MetS) is composed of several conditions and is associated with increased risk for cardiovascular disease and diabetes mellitus (DM). Components of MetS include abdominal obesity, insulin resistance, dyslipidemia, hypertension, and proinflammatory and prothrombotic status [1]. Poor eating habits together with sedentary lifestyle have caused a dramatic increase in the prevalence of MetS as an epidemic throughout the world. According to the National Health and Examination Survey (NHANES) 2003-2006, approximately 34\% of people studied fulfilled the National Cholesterol Education Program Adult Treatment Panel III (NCEP ATPIII) revised criteria for MetS [2]. These risk factors lead to cardiovascular diseases and type 2 diabetes as the next step. In order to achieve sustained metabolic health, factors causing MetS should not be overlooked.

\section{DISCUSSION}

Medical nutritional therapy helps clinical amelioration as well as being cost effective. American Diabetes Association emphasizes on the complementary role and importance of changes made in lifestyle and patient education [3, 4]. A diet targeting to correct blood glucose, blood pressure and lipid profile is of importance to reduce risk factors of cardiovascular diseases, coronary heart diseases and stroke as well as diabetes. Studies have shown weight loss has been accompanied with increased HDL levels, *Address correspondence to this author at the Internal Medicine Department,
İstanbul Medeniyet University, Turkey; Tel: 00905322923159;

Fax: 00902165655526; E-mail: banualpaslan@gmail.com and reduction in triglyceride levels and blood pressure [5-7].

Humans need energy to maintain life. The energy needed is used for both metabolic functions and daily physical activities [8]. If one gets energy equal to the energy consumed, his/her weight would not change. Energy taken more than needed is stored as fat in the body. Energy that is taken less than consumed leads to weight loss. This is defined as energy balance. To lose weight energy deficit is a must. It can be achieved with reduced calorie intake with food or increased calorie consumption with exercise or with the combination of both.

It is being long studied that how ideal nutrition is needed to be. There are various diet types: diets with low carbohydrates, vegetable based diets (veganvegetarian), DASH (Dietary Approach to Stop Hypertension) diet, Mediterranean diet, Zone diet, etc.

Diets with low carbohydrates are based on nutrients with fat and protein. Meat, milk, seafood, fat food and nuts are consumed abundantly and consumed carbohydrate percent is less than $30-40 \%$ of total calorie intake. While fruits and vegetables are main choice in carbohydrate consumption, sweet and floury foods are avoided. Some diets restrict carbohydrate intake sufficiently to cause ketosis (ketogenic diets), as in the induction phase of Atkins diet. There is some evidence that a low-carbohydrate diet may help people lose weight more quickly than a low-fat diet $[9,10]$ and may help them maintain that weight loss. More evidence of the heart benefits from a lower-carbohydrate approach comes from a randomized trial known as the Optimal Macronutrient Intake Trial for Heart Health (OmniHeart) [11]. 
Low fat diet consists of vegetables, fruits, starch containing products (bread, pretzel, pasta, whole grain food), non-fat protein and reduced fat milk. In this diet total and saturated fat consumption is reduced. Ornish et al. demonstrated that lifestyle changes can cause a regression in coronary atherosclerosis [12].

Vegetable based diets include vegan and vegetarian diets. While in vegan diets, consuming meat and other animal products are refrained, in vegetarian diets egg (ovo) and/or milk products (lacto) may be consumed. Vegetable based diets decrease chronic disease risk due to less intake of saturated fat and cholesterol and increased intake of fruits, vegetables, nuts, fiber and soya products.

Mediterranean diet is rich in fruits, vegetables, legumes, bread and other unrefined cereals, grains, beans, nuts and seeds. Olive oil is the key monounsaturated fat source. Dairy products (mostly as cheese and yoghurt), fish and poultry are consumed in moderate amounts, whereas egg consumption is limited to zero to four eggs weekly. Limited red meat and moderate wine consumption is also recommended.

DASH (Dietary Approach to Stop Hypertension) diet encourages fruits, vegetables, whole grains, and low-fat dairy foods; includes meat, fish, poultry, nuts, and beans while limiting sugar-sweetened foods and beverages, red meat, and saturated fats.

While many patients find weight loss difficult to achieve, exercise and dietary changes that can lower blood pressure and improve lipid levels will further improve insulin resistance, even in the absence of weight loss. Thus, the investigation of food components that may deal with metabolic syndrome features is an important field for ameliorate and facilitate dietary based therapies.

There are many research comparing different diets with each other. In a study comparing Atkins (low carbohydrate diet), Ornish (low fat diet) and Weight watchers diet (energy restricted diet) and Zone diet (a balanced combination of primary nutrients) participants were randomized into four diet groups. Results of this study has shown similar weight loss in four groups while showing less permanence in Atkins and Ornish which are based on one type nutrition. Due to randomization people were not allowed to choose diets that they could better comply and this can make a bias in attendance level [13].

Although there are studies to determine optimal combination of primary nutrients for patients with diabetes, a systematic review on this subject has shown there isn't an ideal primary nutrient ratio and these ratios should all be personalized [14]. Also, factors like metabolic situation (lipid profile, renal function) and /or food choices should be considered. The amount and the ingredient of the carbohydrate consumed should be adjusted with caution to have a better control on postprandial glucose levels. American Diabetes Association advices to consume approximately $45 \%$ of total macronutrients as carbohydrates. Refined carbohydrates should be avoided and whole grain food ought to be preferred $[3,15]$.

The researches on diets such as Mediterranean, DASH and vegetable based diets indicate that restricting fat and carbohydrates are effective in diabetes treatment $[7,12,16-18]$.

Studies have proven beneficial effects of Mediterranean diet on cardiovascular risk factors such as lipids, blood pressure, triglyceride levels [7, 14, 15]. The consumption of Mediterranean dietary patterns rich in olive oil has a profound influence on health outcomes, including obesity, metabolic syndrome and diabetes mellitus. Olive oil besides having high monounsaturated content, contains other minor components with biological properties.

In studies on vegetarian and vegan diets, these diets do not have a significant impact on glucose control if necessary calorie reduction is not made [16, 19-21]. Also in Mediterranean diet energy restriction is a must to obtain glycemic control [14].

Like other diets with reduced fat levels, Mediterranean diet is highly recommended to patients with dyslipidemia. It is also suggested that nutrition with reduced fat is beneficial only because of less energy intake and weight loss [3, 22]. Not only decreasing total fat intake and restricting diet cholesterol, but also changing saturated and trans fats with polyunsaturated and monounsaturated ones all benefits to total cholesterol, LDL cholesterol and triglyceride levels. Reduction of saturated fat to less than $7 \%$ of total calorie and decreasing dietary cholesterol to less than $200 \mathrm{mg}$ leads to a $9-12 \%$ decrease in LDL cholesterol levels [23]. Nutrients such as nuts, soya protein, omega 3 fatty acids (i.e. Eicosapentaenoic Acid = EPA and Dokosaheksaenoic Acid = DHA), sterol and stanoles improves dyslipidemia, but extra care should be given to maintain isocaloric state [24-28]. Research has shown that reduced fat diets decrease total cholesterol and LDL cholesterol while reduced carbohydrate diets 
have the most significant impact on triglyceride and HDL cholesterol levels [29]. In DIRECT study, the reduction of total cholesterol/LDL cholesterol ratio was $20 \%$ in fat restricted diet and $12 \%$ in carbohydrate restricted diet [30]. For Mediterranean diet in which fish, nuts, vegetable and whole grain consumption is moreover emphasized, this effect is strong [31].

In hypertensive patients restriction in salt consumption is recommended. Sodium amount taken with food should be less than $2300 \mathrm{mg}$. Yet, recent studies introduce new perspectives. In PURE study, the optimum sodium amount is declared as 3 to $6 \mathrm{~g} /$ day, which is equivalent to maximum $15000 \mathrm{mg}$ salt consumption [32].

Along with sodium consumption a diet rich in potassium, magnesium and fiber has beneficial impacts on blood pressure control. Fruit and vegetables are not only rich in potassium magnesium and fiber, but also poor in sodium, so they should be consumed more. Fruit juices do not have fiber thus they are not as beneficial as the fruit itself. Nuts, seeds, fruits, meat with reduced fat and poultry are rich in magnesium. Aforementioned eating style is called DASH diet and shown to reduce blood pressure and cardiovascular risk factors. It is selected as the best eating pattern for normal population [33, 34].

\section{CONCLUSION}

For patients with MetS, diet recommendations for diabetes, dyslipidemia and hypertension should be synthesized [35]. Patients should consume according to their calorie needs defining good and bad food. They should focus on foods with low calorie and high nutritional values. Calorie taken by sodium, fat, sugar and refined carbohydrates should be restricted. Vegetable, fruit, whole grain, skimmed milk and dairy products, seafood, fat reduced meat, poultry, egg, beans and legume, nuts and seed consumption must be increased. In order to live a healthy life changes should be made especially in patients with metabolic syndrome.

\section{REFERENCES}

[1] Alberti KG, Eckel RH, Grundy SM. Harmonizing the metabolic syndrome: a joint interim statement of the International Diabetes Federation Task Force on Epidemiology and Prevention; National Heart, Lung, and Blood Institute; American Heart Association; World Heart Federation; International Atherosclerosis Society; and International Association for the Study of Obesity. Circulation 2009; 120(16): 1640-5.

http://dx.doi.org/10.1161/CIRCULATIONAHA.109.192644
Ervin RB. Prevalence of metabolic syndrome among adults 20 years of age and over, by sex, age, race and ethnicity, and body mass index: United States, 2003-2006. Natl Health Stat Report 2009; (13): 1-7.

[3] American Diabetes Association. Standards of Medical Care in Diabetes. Diabetes Care 2015; 38(Suppl 1): S4.

[4] Inzucchi SE, Bergenstal RM, Buse JB. Management of hyperglycemia in type 2 diabetes 2015: a patient-centered approach: Update to a position statement of the American Diabetes Association (ADA) and the European Association for the Study of Diabetes (EASD). Diabetes Care 2015; 38: 140-9.

http://dx.doi.org/10.2337/dc14-2441

[5] Mark Espeland, Look AHEAD Research Group. Reduction in weight and cardiovascular disease risk factors in individuals with type 2 diabetes: one-year results of the Look AHEAD trial. Diabetes Care 2007; 30: 1374-83. http://dx.doi.org/10.2337/dc07-0048

[6] Larsen RN, Mann NJ, Maclean E, Shaw JE. The effect of high-protein, low-carbohydrate diets in the treatment of type 2 diabetes: a 12 month randomised controlled trial. Diabetologia 2011; 54: 731-740.

http://dx.doi.org/10.1007/s00125-010-2027-y

[7] Esposito K, Maiorino MI, Ciotola M, Di Palo C, Scognamiglio $P$, Gicchino M, Petrizzo M, Saccomanno F, Beneduce F, Ceriello A, Giugliano D. Effects of aMediterranean-style diet on the need for antihyperglycemic drug therapy in patients with newly diagnosed type 2 diabetes: a randomized trial. Ann Intern Med 2009; 151: 306-14.

http://dx.doi.org/10.7326/0003-4819-151-5-200909010$\underline{00004}$

[8] U.S. Department of Health and Human Services and U.S Department of Agriculture. Dietary Guidelines for Americans, 2010 [Internet]. Available from www.health.gov/ dietaryguidelines/. Accessed 30 June 2011.

[9] Foster GD, Wyatt HR, Hill JO, Brian G, McGuckin EM, Carrie Brill BS, Mohammed BS, Szapary PO, Rader DJ, Edman JS, Klein $\mathrm{S}$. A randomized trial of a low-carbohydrate diet for obesity. N Engl J Med 2003; 348: 2082-90.

http://dx.doi.org/10.1056/NEJMoa022207

[10] Samaha FF, Iqbal N, Seshadri P, Chicano KL, Daily DA, Mc Grory J, Williams T, Williams M, Gracely EJ, Stern L. A lowcarbohydrate as compared with a low-fat diet in severe obesity. N Engl J Med 2003; 348: 2074-81. http://dx.doi.org/10.1056/NEJMoa022637

[11] Appel LJ, Sacks FM, Carey VJ, Obarzanek E, Swain JF, Miller ER, Conlin PR, Erlinger TP, Rosner BA, Laranjo NM, Charleston J, McCarron P, Bishop LM, for the OmniHeart Collaborative Research Group et al. Effects of protein, monounsaturated fat, and carbohydrate intake on blood pressure and serum lipids: results of the OmniHeart randomized trial. JAMA 2005; 294: 2455-64.

http://dx.doi.org/10.1001/jama.294.19.2455

[12] Ornish DM, Brown SE, Scherwitz LW, Brown SE, Billings JH, Scherwitz LW, Armstrong WT, Ports TA, McLanahan SM, Kirkeeide RL, Gould KL, Brand RJ. Can lifestyle changes reverse coronary heart disease? Lancet 1990; 336: 129-33. http://dx.doi.org/10.1016/0140-6736(90)91656-U

[13] Dansinger ML, Gleason JA, Griffith JL, Selker HP, Schaefer EJ. Comparison of the Atkins, Ornish, Weight Watchers, and Zone Diets for Weight Loss and Heart Disease Risk Reduction. JAMA 2005; 293: 43-53. http://dx.doi.org/10.1001/jama.293.1.43

[14] Wheeler ML, Dunbar SA, Jaacks LM, Karmally W, MayerDavis EJ, Wylie-Rosett J, Yancy WS. Macronutrients, food groups, and eating patterns in the management of diabetes: a systematic review of the literature, 2010. Diabetes Care 2012; 35: 434-45.

http://dx.doi.org/10.2337/dc11-2216 
[15] Turner-McGrievy GM, Barnard ND, Cohen J, Jenkins DJ, Gloede L, Green AA. Changes in nutrient intake and dietary quality among participants with type 2 diabetes following a low-fat vegan diet or a conventional diabetes diet for 22 weeks. J Am Diet Assoc 2008; 108: 1636-45. http://dx.doi.org/10.1016/j.jada.2008.07.015

[16] Barnard ND, Cohen J, Jenkins DJ, Turner-McGrievy G, Gloede L, Jaster B, Seidl K, Green AA, Talpers S. A low-fat vegan diet improves glycemic control and cardiovascular risk factors in a randomized clinical trial in individuals with type 2 diabetes. Diabetes Care 2006; 29: 1777-83. http://dx.doi.org/10.2337/dc06-0606

[17] Azadbakht L, Fard NR, Karimi M, Baghaei MH, Surkan PJ, Rahimi M, Esmaillzadeh A, Willett WC. Effects of the Dietary Approaches to Stop Hypertension (DASH) eating plan on cardiovascular risks among type 2 diabetic patients: a randomized crossover clinical trial. Diabetes Care 2011; 34: 55-7. http://dx.doi.org/10.2337/dc10-0676

[18] Stern L, Iqbal N, Seshadri P, Chicano KL, Daily DA, McGrory J, Williams M, Gracely EJ, Samaha FF. The effects of lowcarbohydrate versus conventional weight loss diets in severely obese adults: one-year follow-up of arandomized trial. Ann Intern Med 2004; 140: 778-85.

http://dx.doi.org/10.7326/0003-4819-140-10-200405180$\underline{00007}$

[19] Nicholson AS, Sklar M, Barnard ND, Gore S, Sullivan R, Browning S. Toward improved management of NIDDM: a randomized, controlled, pilot intervention using a low fat, vegetarian diet. Prev Med 1999; 29: 87-91. http://dx.doi.org/10.1006/pmed.1999.0529

[20] Tonstad S, Butler T, Yan R, Fraser GE. Type of vegetarian diet, body weight, and prevalence of type 2 diabetes. Diabetes Care 2009; 32: 791-6. http://dx.doi.org/10.2337/dc08-1886

[21] Barnard ND, Cohen J, Jenkins DJ, Turner-McGrievy G, Gloede L, Green A, Ferdowsian H. A low-fat vegan diet and a conventional diabetes diet in the treatment of type 2 diabetes: a randomized, controlled, 74-wk clinical trial. Am J Clin Nutr 2009; 89: 1588S-1596S.

http://dx.doi.org/10.3945/ajcn.2009.26736H

[22] Kodama S, Saito K, Tanaka S, Maki M, Yachi Y, Sato M, Sugawara A, Totsuka K, Shimano $H$. Influence of fat and carbohydrate proportions on the metabolic profile in patients with type 2 diabetes: a metaanalysis. Diabetes Care 2009; 32: 959-65.

http://dx.doi.org/10.2337/dc08-1716

[23] Wing RR, Bolin P, Brancati FL, Bray GA, Clark JM, Coday M, Crow RS, Curtis JM, Egan CM, Espeland MA, Evans M, Foreyt JP, Ghazarian S, Gregg EW, Harrison B, Hazuda HP, Hill JO, Horton ES, Hubbard VS, Jakicic JM, Jeffery RW, Johnson KC, Kahn SE, Kitabchi AE, Knowler WC, Lewis CE, Maschak-Carey BJ, Montez MG, Murillo A, Nathan DM, Patricio J, Peters A, Pi-Sunyer X, Pownall H, Reboussin D, Regensteiner JG, Rickman AD, Ryan DH, Safford $M$, Wadden TA, Wagenknecht LE, West DS, Williamson DF, Yanovski SZ. Look AHEAD Research Group. Cardiovascular effects of intensive lifestyle intervention in type 2 diabetes. $\mathrm{N}$ Engl J Med 2013; 369: 145-54.

http://dx.doi.org/10.1056/NEJMoa1212914

[24] Griel AE, Kris-Etherton PM. Tree nuts and the lipid profile: a review of clinical studies. Br J Nutr 2006; 96(Suppl 2): S68S78.

http://dx.doi.org/10.1017/BJN20061866
[25] Mukuddem-Petersen J, Oosthuizen W, Jerling JC. A systematic review of the effects of nuts on blood lipid profiles in humans. J Nutr 2005; 135(9): 2082-9.

[26] Reynolds K, Chin A, Lees KA, Nguyen A, Bujnowski D, He J. A meta-analysis of the effect of soy protein supplementation on serum lipids. Am J Cardiol 2006; 98(5): 633-40. http://dx.doi.org/10.1016/j.amjcard.2006.03.042

[27] Katan MB, Grundy SM, Jones P. Stresa Workshop Participants. Efficacy and safety of plant stanols and sterols in the management of blood cholesterol levels. Mayo Clin Proc 2003; 78(8): 965-78. http://dx.doi.org/10.1016/S0025-6196(11)63144-3

[28] Von Schacky C, Harris WS. Cardiovascular benefits of omega-3 fatty acids. Cardiovasc Res 2007; 73(2): 310-5. http://dx.doi.org/10.1016/j.cardiores.2006.08.019

[29] Nordmann AJ, Nordmann A, Briel M, Keller U, Yancy WS Jr, Brehm BJ, Bucher HC. Effects of low-carbohydrate vs low-fat diets on weight loss and cardiovascular risk factors: a metaanalysis of randomized controlled trials. Arch Intern Med 2006; 166(3): 285-93 http://dx.doi.org/10.1001/archinte.166.3.285

[30] Shai I, Schwarzfuchs D, Henkin Y, Shahar DR, Witkow S, Greenberg I, Golan R, Fraser D, Bolotin A, Vardi H, TangiRozental O, Zuk-Ramot R, Sarusi B, Brickner D, Schwartz Z, Sheiner E, Marko R, Katorza E, Thiery J, Fiedler GM, Blüher $M$, Stumvoll M, Stampfer MJ. Dietary Intervention Randomized Controlled Trial (DIRECT) Group. Weight loss with a low-carbohydrate, Mediterranean, or low-fat diet $\mathrm{N}$ Engl J Med 2008; 359(3): 229-41.

http://dx.doi.org/10.1056/NEJMoa0708681

[31] Estruch R, Martínez-González MA, Corella D, Salas-Salvadó J, Ruiz-Gutiérrez V, Covas MI, Fiol M, Gómez-Gracia E, López-Sabater MC, Vinyoles E, Arós F, Conde M, Lahoz C, Lapetra J, Sáez G, Ros E; PREDIMED Study Investigators. et al. PREDIMED Study Investigators. Effects of a Mediterranean-style diet on cardiovascular risk factors: a randomized trial. Ann Intern Med 2006; 145(1): 1-11. http://dx.doi.org/10.7326/0003-4819-145-1-200607040$\underline{00004}$

[32] O'Donnell M, Mente A, Rangarajan S, McQueen MJ, Wang $X$, Liu L, Yan H, Lee SF, Mony P, Devanath A, Rosengren A, Lopez-Jaramillo P, Diaz R, Avezum A, Lanas F, Yusoff K, lqbal R, llow R, Mohammadifard N, Gulec S, Yusufali AH, Kruger L, Yusuf R, Chifamba J, Kabali C, Dagenais G, Lear SA, Teo K, Yusuf S, PURE Investigators. Urinary Sodium and Potassium Excretion, Mortality, and Cardiovascular Events. N Engl J Med 2014; 371: 612-23. http://dx.doi.org/10.1056/NEJMoa1311889

[33] Sacks FM, Svetkey LP, Vollmer WM, Appel LJ, Bray GA Harsha D, Obarzanek E, Conlin PR, Miller ER 3rd, SimonsMorton DG, Karanja N, Lin PH. DASH-Sodium Collaborative Research Group. DASH-Sodium Collaborative Research Group. Effects on blood pressure of reduced dietary sodium and the Dietary Approaches to Stop Hypertension (DASH) diet. N Engl J Med 2001; 344: 3-10.

http://dx.doi.org/10.1056/NEJM200101043440101

[34] Appel LJ, Moore TJ, Obarzanek E, Vollmer WM, Svetkey LP, Sacks FM, Bray GA, Vogt TM, Cutler JA, Windhauser MM, Lin PH, Karanja N. DASH Collaborative Research Group. A clinical trial of the effects of dietary patterns on blood pressure. NEngl J Med 1997; 336: 1117-24. http://dx.doi.org/10.1056/NEJM199704173361601

[35] Kaur J. A comprehensive review on metabolic syndrome. Cardiology research and practice 2014; (2014). http://dx.doi.org/10.1155/2014/943162 